Article

\title{
Narratives of Territorial Cohesion and Economic Growth: A Comparative Study
}

\author{
Tatjana Boczy ${ }^{1, *}$ and Marta Margherita Cordini ${ }^{2}$ \\ ${ }^{1}$ Department of Sociology, University of Vienna, 1010 Vienna, Austria; E-Mail: tatjana.boczy@univie.ac.at \\ 2 Department of Architecture and Urban Studies, Polytechnic of Milan, 20133 Milan, Italy; E-Mail: marta.cordini@polimi.it \\ * Corresponding author
}

Submitted: 15 June 2020 | Accepted: 14 September 2020 | Published: 3 December 2020

\begin{abstract}
The ability of regions to develop new productive capacities and to address the needs of inhabitants has become central in the EU agenda to trigger cohesion, sustainable growth and equality. This ability does not derive only from material assets but also from cognitive ones, such as trust, ways of cooperation, governance cultures and sense of belonging. Cognitive aspects are in fact fundamental in making the most of the greater potential of territorial features. Using the concept of territorial capital, we investigate this mix between material and cognitive assets in regional planning discourses. Territorial capital raises issues of spatial diversity and inequality as questions of access. Starting from the theoretical framework suggested by Servillo, Atkinson, and Russo (2011) on attractiveness and mobilization strategies, this article addresses the issue of territorial inequalities on material and cognitive bases by analysing mobilization discourses on territorial capital at a regional scale in Italy and Austria. The investigation of three case studies at different territorial scales (urban, suburban and rural) in each country allows both intra-regional and inter-regional comparison. By mapping the discursive structures of local economic development documents and key-actor interviews, we analyse the different mobilizing strategies in these contexts. Comparing inter-regional mobilization provides an in-depth insight into differences as well as similarities of cohesion strategies in regional planning on multiple levels. This can spark new territorially sensitive schemes for further sustainable socio-economic and equalising development that connects with the social structures on the ground.
\end{abstract}

\section{Keywords}

cognitive capital; cohesion; mobilizing strategies; regional planning; territorial capital

\section{Issue}

This article is part of the issue "Cohesion in the Local Context: Reconciling the Territorial, Economic and Social Dimensions," edited by Anja Jørgensen (Aalborg University, Denmark), Mia Arp Fallov (Aalborg University, Denmark), Rikke Skovgaard Nielsen (Aalborg University, Denmark), Hans Thor Andersen (Aalborg University, Denmark) and Maja de Neergaard (Aalborg University, Denmark).

(C) 2020 by the authors; licensee Cogitatio (Lisbon, Portugal). This article is licensed under a Creative Commons Attribution 4.0 International License (CC BY).

\section{Introduction}

The central role of regions in contributing to growth has been made clear in the EU agenda since the 2000s. At the same time, it has been stated that the ability to generate economic growth is strictly linked to the social cohesion of a territory (European Commission, 2005). Cohesion policies, developed by the EU, were drawn up with the specific goal of helping regions to use their assets and to benefit from all their potentials (Fratesi \& Perucca, 2014).

This objective gave rise to the relevance not only of material features of territory but also of cognitive ones. On this, in 2001 the OECD promoted the idea of territorial capital, listing a variety of material and non-material factors (OECD, 2001). The European Commission (2005) resumed the same concept highlighting the role of territorial policies in making territorial capital effective for 
growth; in other words, enhancing the mobilization of local capital. The topic of mobilizing territorial capital at regional levels raises issues of territorial inequalities, considering not only the diversity among European regions but also intra-regional diversity. Looking at the mobilization of territorial capital with a focus on inequalities means not only considering the differences in terms of assets, be they material or non-material, but also the governance, institutional arrangements, collaboration culture, identity and networks that characterize each locality. In this sense, the mobilization or the lack of mobilizing of territorial capital is usually legitimized by a public discourse that can support, foster or hinder it.

Moving from the theoretical framework suggested by Servillo, Atkinson, and Russo (2011) on attractiveness and mobilization strategies, this article investigates mobilization in the light of territorial inequalities. We do this by analysing mobilization strategies at regional levels and by adopting a comparative case study approach that makes it possible to both interpret and identify relations (Ragin, 2014, pp. 35-36). Taking into consideration three cases at diverse territorial levels (urban, suburban and rural) in two countries (Austria and Italy), we suggest a comparison in order to see how the mobilization of territorial capital is enhanced or hindered. The methodology is based on secondary data, key-actor interviews and policy discourse analysis (see the Supplementary Material for more details).

The article starts with a first part that describes the theoretical discussion on territorial capital and its mobilization. A second part presents the cases, focusing on the main socio-demographic features and the territorial assets. A third part is devoted to the analysis of the strategy discourse relating to territorial capital mobilization and interviews with key informants for each locality in the two countries. Finally, the last part concludes with an analytical comparison and final remarks.

\section{Territorial Assets, Mobilization and Inequality}

Stemming from the idea of local milieu (Maillat, 1995), territorial capital entails both material and cognitive assets. While material aspects are easily associated with locally available resources, cognitive aspects are often lost in discussions analysing contextual conditions. A local milieu is defined based on the following characteristics: (1) a group of actors relatively autonomous in taking decisions and formulating strategies, (2) a specific set of material and immaterial elements, (3) institutional elements and cooperation between local actors used as a basis, and (4) internal self-regulating dynamics and the ability of actors to find new solutions as their competitive environment changes.

The milieu is a cognitive concept, which assembles the behaviours of its protagonists and enhances their collective learning. According to the original definition, the milieu is also characterized by a strong propensity towards innovation (Maillat, 1995). As Servillo et al.
(2011) observe, he original definition of milieu does not imply any form of local dynamics that risks describing the territory as a simple container of material or immaterial goods. Picking up a more dynamic view, the OECD introduced the comprehensive concept of territorial capital in 2001. It is defined as the system of territorial assets of an economic, cultural, social and environmental nature that ensure the development potential of places.

The potential of this approach resides in the recognition of possible interactions between assets of different kinds: private or public goods interacting with knowledge or innovation capability and cooperation networks. Thereby, the concept of territorial capital introduces a shift from a functional to a cognitive approach. Local competitiveness is identified not only in the presence of skilled labour or the availability of capital but also in creativity, local trust and a sense of belonging. It implies localized externalities, localized production activities, traditions, skills and know-how (Camagni, 2009; Capello, Caragliu, \& Nijkamp, 2009). Together, they build a system of proximity relationships that enhance the static and dynamic productivity of local factors. Territorial capital can therefore be conceived as "the set of localized assets that constitute the competitive potential of a given territory" (Camagni \& Capello, 2013, p. 1387). The economic role of territorial capital resides in the enhancing efficiency and productivity of local activities. The attempt to measure the territorial capital by Camagni and Capello $(2013$, p. 1398) shows "an intermediate class of club goods or impure public goods" that imply a relational nature, "and which appear to be of great importance in terms of the governance of the local development process."

The main difficulty in transposing this framework into empirical applications lies in the complexity of the set of assets that define territorial capital and, consequently, in the resulting measurement problems (Affuso, Camagni, \& Capello, 2011; Perucca, 2014). We suggest using discursive approaches to filter this complexity (Atkinson, Held, \& Jeffares, 2011). Besides the assets that make up territorial capitals, policies and narratives contribute to representing and evaluating the resources of any single territory, enforcing or hindering their mobilization. Public authorities and stakeholders, who usually hold the central discourse, play a strategic role in triggering mobilization processes in a multilevel governance framework (Servillo et al., 2011). Therefore, this article takes into consideration the public discourse used by these actors to foster economic growth by comparing the results that emerged from the discourse analysis with the data collected from strategy documents and interviews with key informants, which included policymakers, public authorities, business actors and experts of the specific localities. The final aim is then to understand how the narratives conveyed by the public discourses hinder or enforce the mobilization of territorial capital with the objective of economic growth in a context characterized by diverse local features. The article seeks to answer: What local 
conditions of cognitive assets hinder or enforce the mobilization of territorial capital?

We arrive at a reflection on diverse localities, by comparing three local contexts in two countries (Austria and Italy). We chose localities within one geographical region that has had socio-economic interventions by relevant development strategies in the last 30 years (after de-industrialization). At the same time, these localities show internal social and economic inequalities in terms of access to vital services and life-chances. The cases have been labelled as rural, suburban and urban to indicate specific features related mostly to demographic differences and the structure of the local economy. Table 1 sums up some of the main characteristics.

\section{Case Studies}

\subsection{Italian Case Studies}

Lombardy is the most populated region of Italy. Milan, the regional capital, has been one of the leading industrial centres since 1900 . The region shows a high degree of heterogeneity in terms of socio-demographic indicators (such as population change or immigration) and socio-economic ones (unemployment rate, female participation in the labour market). This internal heterogeneity represents a challenge for the design of cohesion policies and the fostering of economic growth. The three local cases discussed here are Milan, as the urban case, Legnano, the suburban, and the rural case of Oltrepo' Pavese.
Milan is the central economic and financial hub of Northern Italy with a population of 1.370 million inhabitants. It features a multi-sectoral economy, generally dominated by the advanced tertiary sector (Cucca, 2010). The city's governance arena is populated by a multiplicity of diverse actors (business actors, tertiary sector, community actors) with the subsequent retrenchment of the local authority from some relevant issues of the local agenda. This also derives from a long history and tradition of Milanese civil society. Milan shows layers of the society engaged in development and solidarity. Moreover, the city displays a significant amount of intangible resources: It is the Italian capital in terms of start-ups, home to public and private universities, research centres, cultural institutions and innovation hubs. These factors have flowed into a flourishing of public-private partnerships that work successfully because of considerable amounts of private resources. Despite a race towards growth and innovation, the city is often described as a two-speed city, indicating the increasing polarization occurring within the urban context. Milan copes with a general impoverishment of the population, spreading inequalities and increasing social polarization. The distribution of the population exemplifies this increasing polarization: a heterogeneous and scattered periphery with a low level of residential segregation, the opposite of a strongly homogenous city centre with a concentration of wealthy members of the population.

Legnano lies in the Metropolitan Area of Milan, about 20 kilometres from the Milan city centre. The town is

Table 1. Main features of the selected cases.

\begin{tabular}{|c|c|c|c|c|c|c|}
\hline & \multicolumn{3}{|c|}{ Italy } & \multicolumn{3}{|c|}{ Austria } \\
\hline & $\begin{array}{l}\text { Milan } \\
\text { (urban) }\end{array}$ & $\begin{array}{l}\text { Legnano } \\
\text { (suburban) }\end{array}$ & $\begin{array}{c}\text { Oltrepo' } \\
\text { Pavese } \\
\text { (rural) }\end{array}$ & $\begin{array}{l}\text { Vienna } \\
\text { (urban) }\end{array}$ & $\begin{array}{l}\text { Kleinregion } \\
\text { Ebreichsdorf } \\
\text { (suburban) }\end{array}$ & $\begin{array}{c}\text { Waldviertler } \\
\text { Kernland } \\
\text { (rural) }\end{array}$ \\
\hline Population (2019) & $1,351,562$ & 60,259 & 13,590 & $1,867,582$ & 36,601 & 14,022 \\
\hline $\begin{array}{l}\text { 5-year population change } \\
(2011-2016)\end{array}$ & $0.08 \%$ & $0.04 \%$ & $-0.03 \%$ & $8.76 \%$ & $8.43 \%$ & $-3.13 \%$ \\
\hline Unemployment (2011) & & $8.4 \%$ & & & $4.6 \%$ & \\
\hline Local unemployment (2015) & $6.8 \%$ & $8.3 \%$ & $5 \%$ & $13.3 \%$ & $7.5 \%$ & $3.4 \%$ \\
\hline $\begin{array}{l}\text { Employment primary } \\
\text { sector (2015) }\end{array}$ & & $3.6 \%$ & & & $4 \%$ & \\
\hline $\begin{array}{l}\text { Local employment primary } \\
\text { sector (2015) }\end{array}$ & $0.8 \%$ & $0.9 \%$ & $11.1 \%$ & $0.1 \%$ & $4.3 \%$ & $26.2 \%$ \\
\hline
\end{tabular}

Notes: Legnano and Kleinregion Ebreichsdorf, despite the diverse size in term of population, share some typical features of suburban localities such as being commuter towns. The rural areas are more similar in terms of population size and they both are characterised by depopulation and the dominant role of agriculture. The following section gives context details on each case locality and digs deeper into territorial assets. Unemployment is ratio by active population. Local employment in primary sector by total workforce-own calculation based on official national statistics. Employed by sector of total workforce numbers are based on Statistics Austria municipal data (authors' own calculation). Sources: Statistics Austria (n.d.), Italian National Institute of Statistics (n.d.), Eurostat (n.d.; last accessed 11 August 2020), AMS Austria (2018), Eurostat as cited in Grozea-Helmenstein, Helmenstein, and Neumüller (2016, p. 24). 
linked to Milan by a good transportation system that permits commuting. Its dependency on Milan is softened by the fact that Legnano is the biggest and leading municipality of the Alto Milanese area, one of the most industrialized and populated areas of the country. From the end of the 19th century, Legnano has become the main city in a cluster of industrial development centres, occupying a crucial position in the textile and mechanical engineering industries at a national level (Tosi \& Vitale, 2011). During the de-industrialization process in the 1980s and 1990s, big firms and industries started to decline and partially or entirely closed in the beginning of the 2000s. This change not only created unemployment but challenged the narrative about the identity of Legnano's longterm inhabitants, strongly linked to the world of industry. The decline in industrial activities has been only partially offset by the growth in the construction and service provision sectors (Tosi \& Vitale, 2011). Legnano's main asset is the quality of its local enterprises (SMEs). After the de-industrialization, these enterprises have been trying to re-invent themselves and adapt to the international context. Their quality is linked to a widespread entrepreneurial spirit that is also the leading dimension of the territorial identity.

Oltrepo' Pavese is located in the province of Pavia and includes 18 municipalities, most of which have fewer than 1000 inhabitants. The Northern portion of the region is mainly hilly, while the Southern area is part of the Northern Apennines. Because of natural obstacles in the area, mobility has always been an issue for commuting and service delivery. The territorial capital in Oltrepo' Pavese is connected to the natural features, local history and culture. The main economic opportunities are represented by agri-food, slow-tourism and biodiversity. Oltrepo' Pavese's main challenge is to overcome the economic marginalization caused mainly by two demographic processes: depopulation and ageing. Nevertheless, this challenge is hardly taken up by the local (public) actors. In general, a set of features hindering growth and development is identifiable in the area: low entrepreneurial aspiration, conflicting social attitudes, lack of business vision and clientelism dynamics that characterize local politics.

\subsection{Austrian Case Studies}

The Austrian case study region is in the north-eastern part of the country. It consists of the Bundesländer Lower Austria and Vienna. While Lower Austria is the largest Bundesland, Vienna is the smallest in terms of territorial size. Moreover, Vienna is the densest city in the country, while Lower Austria's territory has the most farming land per square kilometre in the country. The three local cases chosen for this research are Vienna, as the urban case, Kleinregion Ebreichsdorf as the suburban, and Kleinregion Waldviertler Kernland as the rural case.

Vienna counts over 1.8 million inhabitants (2019), which is around one-fifth (21\%) of Austria's popula- tion. Its crucial demographic trend is population growth. Compared to other cities in Austria, Vienna presents itself as a centre for international business in the tertiary sector and international migration. After years of depopulation in Vienna, Austria's accession to the EU in 1995 and the further enlargement of the Union reversed depopulation. The governance arena of the urban case is populated by a multiplicity of diverse actors (interest groups, tertiary sector, business actors) but the local authorities are the main drivers of urban socioeconomic development. This derives from a long tradition of the social-democratic rule and the city's status as a Bundesland. Accordingly, the city's government forms both the city and Land administration and enjoys more autonomy than any other city in the country. Overall, governance is organized collaboratively with a strong influence of the city council and Austrian social partners that represent the institutionalized interests of both workers and employers. The involvement of social partners is not unique to the city of Vienna. However, the city can act almost as a city-state due to its legal status as a Bundesland which allows the city to focus almost exclusively on urban topics. Moreover, as the capital, Vienna hosts vital national institutions which enables vital networks. Public-Private Partnerships are somewhat rare but sought after by the city government according to international best-practice discourses.

The Ebreichsdorf Kleinregion is an inter-municipal collaboration of ten municipalities. It is part of the Lower Austria Bundesland located within the Functional Urban Area of Vienna, 40 kilometres south of it. Traffic connection opportunities differ between municipalities, but the area is quite well connected. The most important demographic trend is population growth. Between 2007 and 2017 , the population in this area grew by $16.5 \%-$ slightly more than Vienna. Mostly, this trend is based on domestic migration. Population growth by immigration and high shares of commuting towards Vienna significantly shaped the Ebreichsdorf Kleinregion in the last ten years. The administrative status is that of a voluntary Kleinregion, an inter-municipal collaboration of ten municipalities (36,601 residents). This governance instrument aims to foster inter-municipal cooperation and is supported by the Bundesland government with extra resources. The Ebreichsdorf Kleinregion was originally founded in 2008 by five municipalities. In 2015, collaboration in the Kleinregion was reinstalled and extended by five more municipalities. Based on the recent expansion, we observe a lot of activities and enthusiasm in media accounts, but some municipalities seem to have a more substantial lead than others. There is no one single company that dominates the region. In 2018, however, the opening of a 'Research and Technology Hub' was advertised by the government of Lower Austria as a significant project for improving the local economy and developing the tertiary economic sector.

Waldviertler Kernland is in the north-western part of Lower Austria. The case lies outside of the functional 
area of Vienna and consists of 14 municipalities $(14,022$ residents). The most significant demographic trends are population decrease and aging. The area is considered peripheral due to the bad connection to motorways and public transport. Since de-industrialization in the 1980s, the locality has lost vital industries and businesses. However, in the early 1980s, new regional planning policies and agencies started to counteract the economic downturn. Regional planning focused on the search for new, locally-based identities and territorial capital (e.g., nature for tourism and health resorts) to spark the local economy. Today, forestry, agriculture and tourism are key for the local economy. The economic structure contrasts with national trends of tertiarization - the role of agriculture and forestry is very high $(26.2 \%)$ due to key farming activities and companies in the area. Still, the share of employment in that sector is also declining slowly. Like the Austrian suburban case, the rural case is a voluntary Kleinregion, an inter-municipal collaboration which has been in operation since 2001 and has implemented several regional development projects. Their focus lies on health and social services, like childcare during summer. They also collaborate on a common regional identity and tourism marketing.

\section{Method and In-The-Field Activities}

Country case selection was based on theoretical sampling (Glaser, 1992; Glaser \& Strauss, 1967/2009) for two national cases with different underlying governance logics (Bonoli, 1997; Esping-Andersen, 1990), but similar external conditions (Ragin \& Becker, 1992) such as the governance structure within the European Union, global competition and the socio-economic development of Europe. Both Italy and Austria are long-term EU member states that have invested in cohesion policies. Regional disparities exist in both countries between thriving places of knowledge economies and de-industrialized zones. The cases chosen within the countries share some local features in terms of assets but differ in governance modalities and collective participation in the policy-making process (tertiary sectors, private actors, and civil stakeholders). The comparison helps to identify similarities and differences in broadly the same external conditions (i.e., EU membership, 2008 financial crisis in Europe; Rihoux \& Grimm, 2006, pp. 43-45). The research investigated in-depth mobilization strategies of territorial capital on a local level by scrutinizing strategies for local development and key-actor discourses. Thereby, a descriptive comparison is achieved that makes it possible to follow up on the mechanism for mobilization in different political economies. A larger country sample would not be able to arrive at such an extensive description of the phenomena.

Our discursive analysis uses 12 strategy documents outlining regional economic development and 12 semistructured key-actor interviews involved in local economic development as public, business or civic agents (for the description of the interview codes used in this article see the Supplementary Material). These discourses outline territorial capital in descriptions of strengths as well as how to tackle identified challenges. We investigated the documents and interviews collected in three steps: (1) mapping a larger sample of collected documents with background information, (2) analysing central documents and interviews in a structural-agentcantered manner (Atkinson et al., 2011), and (3) linguistic performance-oriented ways (Kornberger \& Clegg, 2011). For the first step, we coded descriptions of goals, economic growth, identity and collaboration mechanisms in each document. For a more in-depth analysis of central documents and interviews, we coded them thematically in a deductive way (Mayring, 2007; Schmidt, 2007) operationalizing concepts of territorial capital as descriptions of local strengths and their mobilization. The analysis included the perspective suggested by Gervais, Morant, and Penn (1999) to detect the silence and absence of specific dimensions and positions. We were thereby able to compare what is addressed, but also what has been left out.

\subsection{Urban Mobilization}

Since 2014, Milan has been focusing on becoming a Smart City, able to compete on a global scale. This goal constantly resounds in public narratives, coming from both political and business actors. According to the Smart City programme diffused by the Municipality, economic growth must be pursued with the related goal of social inclusion. This can happen through strategic coordination and synergy between actors (Milan Municipal Council, 2014, p. 1). Intangible goods and networks are considered as resources on which the city should count to grow and guarantee social inclusion. To this end, a pivotal role is assigned to technology and innovation as well as social integration and inclusion. Milan is presented as a city already with the capital to be smart, but in need of a new perspective. This positive narrative aims at gathering the actors needed in order to find a way to exploit the existing assets. However, the modalities through which this participation should be implemented are not specified. Other than citizen involvement, public-private partnerships have acquired more relevance. An example of the new role played by business actors is Assolombarda, an association gathering enterprises in the Province of Milan and its surroundings. The last Assolombarda president describes the network as:

One of the modalities adopted to give shape to this intention has been the constitution of an advisory board for the social responsibility of the enterprise, that is an organism collecting diverse personalities from the Milanese industrial world....This board has started to work lately following three priorities: young, women and culture. (ITUrb1) 
Apart from launching events to bring diverse actors together, there is no clear strategy to make these networks work. The risk is the dispersion of the resources and the creation of networks that lack shared contents. Dynamics of inclusion and exclusion are likely to emerge with some civil society organizations contributing to a general improvement of the city and others being excluded from this process. This oversight makes the threat of a two-speed city more real (ITUrb2).

The hybrid nature of actions presented in the documents is evident especially in the Manifattura Milano. Alongside economic growth ("increasing economic attractiveness," "developing consolidated sectors"), the social vocation appears consistently, "combining innovation, inclusion and sustainability," "rebirth of peripheries" (Municipality of Milan, 2016). Especially the social vocation goal implies the participation of citizens. However, there is no clear consensus about the mobilization capabilities of citizens. A business interviewee (ITUrb3) highlights that there is a restless race towards innovation, but this hyper-activism risks resulting in dispersion and hiding socio-spatial tensions that will remain unsolved.

In terms of mobilizing territorial capital, Vienna tries to use policy bundles to achieve economic growth and cohesion with five-year strategy frameworks and specialized strategies that range from land-use planning to business plans, and a wide range of topics (Vienna Municipal Department 18, 2005, 2014a, 2014b). Similar to Milan, the city administration initiated the process of becoming a Smart City with a full strategy in 2014 (see Vienna Municipal Department 18, 2014b). The city administration has a thorough approach to city planning that tries to incorporate social, economic and ecological issues. However, this holistic planning style mostly remains on paper. Urban key-actor interviewees from the administration indicated that not only has this holistic planning been around for more than 20 years, but that organizational structures make it prone to institutional hurdles:

However, they overlooked the fact that the biggest obstacle to implementation is their administration, which cannot understand this from the outset. So, those on the inside, experts from the internal administration, work together, but the actions of the departments are based on their work programmes. This is incredibly difficult, which means that internal $\mathrm{PR}$ is one of the biggest challenges to make something like this effective. (ATUrb1)

Ultimately, this limits cross-sectoral coordination, even if it is envisioned in strategy papers. Current strategies at the municipal level indicate a perceived growth potential, particularly in the segment of research, technology and innovation. Documents and interviews highlight the city's status as Austria's hub for higher education and tertiary sector workforce. This status is depicted as territori- al capital to create a local knowledge economy and Smart City (Vienna Municipal Department 18, 2014b).

Fostering a culture of collaboration is presented as the solution to many issues. Cross-horizontal collaborations are often presented for solving challenges within the city. The 2014 strategy prominently put regional collaboration forward to create Vienna as a potential "economic hub, workplace and place of living" (Vienna Municipal Department 18, 2014a, p. 93). In the Austrian context, this is not surprising since the institutional social partnership between union, labour and commerce interest groups, is present in every Bundesland and on district levels. However, the strategy document (Vienna Municipal Department 18, 2014a) sets out ways to use these connections in urban development issues like developing programs for underused urban areas and ground floors. Herein, the asset of being the political centre of the country shows, as it is much easier for interest groups, including entrepreneurial networks, to connect and work out solutions (informally).

Politically, the city has a long-standing socialdemocratic rule which includes almost permanent positions of key actors like mayors and town councils. Thereby, strategies form visions that are more riskavoidant and less dynamic but have a solid base for longterm planning.

\subsection{Suburban Mobilization}

The identity of Legnano is strongly connected to its glorious industrial past. This rhetoric is vivid in the document issued in the Strategic Plan of Confindustria Lombardia (Confindustria, 2015). This plan was prepared to inspire local firms. The territory is represented as homogenous, and it is described as a macro-region that belongs to Europe. The aim of promoting a shared identity and a feeling of attachment is evident.

As in the case of Milan, the territorial capital is already considered well-developed to trigger growth. This already existing capital, according to the document, is fostered by a high-level training tradition and longterm experience in school-to-work transition. The proposed clustering strategy is suitable for exploiting the already existing resources, but a cluster implies a shared identity and vision. The discourse contained in the document emphasizes the similarities among the territories, especially the entrepreneurial spirit, the courage of the inhabitants and the capacity of sharing experiences and abilities. Even if 'territorial cohesion' does not appear in the text, this is the only document, among those selected for the analysis in the Italian case, that shows an orientation towards this concept. The strategy describes the industrial cluster as belonging to and participating in wider territorial dynamics (mostly European). The reality constructed is one of a shared identity that would naturally end up in a cluster. This clashes with the general loss of identity that has characterized the territory since the 1980s, which worsened after the 2008 financial crisis 
(Tosi \& Vitale, 2011). The closure of several firms, increasing unemployment, and the abandoned and empty factories have undermined the solidity of the 'entrepreneurial culture,' which is still alive in narratives, but emptied in terms of contents. The investment in local firms that the discourse promotes clashes with the delocalizing policies of recent years.

Some of our interviewees highlight that it is the wealthy population that dominates the discourse, trying to push a mobilization of assets that are not there anymore and are sustained only by a rhetorical representation. The lack of services or the lack of coordination is rarely mentioned as a concern:

This narrative of the Legnano entrepreneurs is conveyed by the same people over time. They are the wealthiest people in Legnano, sharing the same interests. They are a family, not relatives, more a family bound by interests. It has not changed; it has always been like that. (ITSub1)

The Ebreichsdorf Kleinregion focuses mainly on transport and ecological projects. Even though the Ebreichsdorf Kleinregion is an inter-municipal collaboration, its name does not reflect a collective identity; instead, it names just one municipality, mainly the municipality of Ebreichsdorf, which seems to be operating the municipal collaboration strategies. Key agents are that municipality's mayor and the municipal council. As Ebreichsdorf has the most residents within the collaboration, it also harvests more financial resources through taxes. Additionally, its council has good contacts with Bundesland agencies, which is vital for funding.

The documents (Kleinregion Ebreichsdorf Management \& Emrich Consulting, 2011; Kleinregion Ebreichsdorf Management \& NÖ.regional, 2016) describe the high standard of living due to the recreational and rural character of the settlements as its territorial capital. Assets for both residents and businesses are the land available for businesses and the proximity to Vienna. The strategy document from 2015 describes the increase in residents as a strength, but it does not explicitly address how to use this strength in local development. This rhetoric is not always shared by our interviewees and, according to them, especially long-term residents do not share it (ATSub4).

Strategies indicate the wish for stakeholder involvement. However, the documents do not specify anywhere who these are and what their role would be, leading to the assumption that although the Kleinregion management knows that stakeholders and civic society need to be or should be involved, it does not want to or does not know how to activate this collaborative potential: "I think the individual places...have found their identity, but since the Kleinregion is relatively different, I do not know if there is now a common identity" (ATSub3).

Mostly, proposed solutions for local development revolve around identity-building, marketing, transport and digital infrastructure, and environmental protection. The municipalities collaborate to attract businesses. Renewable energy is also on the agenda of municipal collaboration, connecting each municipality (ATSub2).

Although Bundesland agencies support their efforts, internal tensions between municipalities and within them are clear from document analyses and interviews. As is evident in the documents, the Kleinregion would like to have an active community life. Nevertheless, the documents never mention the active involvement of residents. Instead, there is a clear top-down understanding with mayors and city council (of one municipality) drafting strategies. Interviewees outline that "there is no actuator, in Ebreichsdorf there is always fragmentation, and one always waits for something to come from outside and the basis [for locally based action] is so to speak still not existent" (ATSub1).

Also, politically, the town councils are fragmented with split political lines of conservative and progressive politics. This is evident in regular changes of political leadership in municipal councils, different alliances and specialized local political factions.

\subsection{Rural Mobilization}

Oltrepo' Pavese is struggling with isolation and fragmentation issues. The idea of growth is far from being rooted there since not even the idea of a territorial economy is shared by the different communities. The notion of cohesion and economic growth based on territorial assets is usually brought into this context by external actors and is not at all interiorized. These external actors (mostly supra-municipal organizations or foundations from Milan or national programmes) play a vital role in the attempt to mobilize the local, territorial capital. However, their efforts are not successful given the obstacles and the resistance from local actors (mostly mayors). According to interviewees, a cultural shift is needed:

We are trying to make Oltrepo' known for its territorial bio-diversity, meaning the forest, the variety of agricultural products, the animals, the local history, and tradition. Local authorities seem into it right now, but, at the same time, they are making arrangements to host the Enduro Motorcycle Championship next year that of course clashes with promoting and respecting biodiversity. (ITRur1)

The Inner Areas Strategy, a national project that aims at relaunching marginal territories-usually rural or peripheral, sees the territory as a "production factor," including cultural identity, contextual knowledge, environmental and social features, which represent pull factors for virtuous flows and foster the competitiveness of the local economic fabric (Ministry of Territorial Cohesion, 2012). This strategy for relaunching the territory clashes with the strong fragmentation that isolates the municipalities 
from each other. Municipalities are suffocated by the dynamics of clientelism and familism. Local actors are trapped in historical fights and divisions which keep them from participating in collaborative projects: "We organized seminars, meetings, dissemination activities...well, and only one mayor attended them and participated in the project, and it is an anomaly because he is very young and, apparently, he does not care about being voted in again" (Ministry of Territorial Cohesion, 2012). This comment indicates that the only concern among mayors is being re-elected rather than engaging in innovative initiatives. The contrast between the official document glorifying a neglected territorial capital and the interviewees' narrative about disinvestment by local actors is striking.

The Waldviertler Kernland Kleinregion has a long history of bottom-linked regional planning. Well established since 2001, the rural case collaboration's focus is to foster cohesion, the local economy and demographic growth. Local-based development has an even longer history there, as key actors for regional development in Austria started this pursuit in 1982 (Gerhardter \& Gruber, 2000). Small businesses and local initiatives play a big role as their impact is more significant on the community. Documents further highlight nature, agricultural products and traditions as assets as well as family life in the countryside (Kleinregion Waldviertler Kernland Management, 2012, 2016; NÖ.regional, 2015). There is no outlined pursuit of large company settlement (Gerhardter \& Gruber, 2000). Instead, we found a 'cando-on-our-own' attitude, which is also part of the perceived territorial capital and proud identity both in documents and interviews (Kleinregion Waldviertler Kernland Management, 2016): "Well, one says of the Waldviertler that he is hard-working...modest, without taking it to extremes....'A Waldviertler is three people'....In truth, our potential is the people and the mentality of the people that come from here" (ATRur1).

Even though the strategies have limited influence on specific sectoral policy elements, there is a rather high mobilization rate when it comes to promoting territorial capital. Key agents and stakeholders are limited to a handful of people who also have intersecting roles within the communities.

Politically, municipal councils have quite a constant political representation with not much diversity or change of the local political leadership. This more fixed conservative rule in most municipalities is not just a political ideology that remains constant; personnel and key actors also stay quite constant. This affects the streamlining of regional development strategies, especially for mobilizing territorial capital:

There are very many Kleinregionen that just do a bit of municipal cooperation. Others, like us, have put it on a completely different level...we are also taking action in other areas....The government of Lower Austria does not always welcome that....The Kleinregionen mainly have the task of municipal cooperation...in our case this is far more advanced and much more widely spread than is actually desired by the Bundesland government. (ATRur2)

Unlike the Austrian suburban case, the rural case does not incorporate the Bundesland discourse well. Local key actors try to improve local development creatively and show a high level of mobilization. These actors are not solely civilian but have intersecting responsibilities, roles and networks across the communities, businesses and public authorities. This allows them to mobilize local assets and effectively influence local development from strategy planning to implementation. Nevertheless, the issues concerning the rural case are not well transferred upwards to the regional or federal level.

\section{Intra-Regional and Inter-Regional Comparison}

Not surprisingly, the urban cases, Milan and Vienna, are united by a developed local knowledge economy. They have fostered partnerships between public and private sectors (Milan) and between unions and commerce interest groups (Vienna). In general, they display a considerable capacity for getting stakeholders to work towards a common goal. Nevertheless, there is a strong contrast in both cases between the rhetoric describing an inclusive network and the reality that shows, instead, a fragmented and not very inclusive community. There is considerable stress on the role of innovation and technology in the official discourse, but it is hardly embedded in a clear, socially inclusive strategy. In both cases, cohesion is mostly interpreted as being social rather than territorial: 'Territorial cohesion' is almost never referred to in official documents. The two cities differ, instead, in terms of the role of the local authority: In the case of Milan, the municipality plays a detached role, although local authorities are officially in charge of leading alliances. This is linked to the idea of leaving more space and power to non-institutional actors, but it is also due to the high turn-over that characterizes the city's administration. Vienna, on this point, reveals a different pattern, with key actors in administration having almost permanent positions. This leads to long-term, less fragmented and time-constrained planning, increasing the ability to build long-lasting networks. In our urban cases, territorial capital seems to be mobilized and exploited successfully but they still fail to address the matter of inclusion and social cohesion consistently. Especially in Milan, this mobilization fails to promote equality, but rather it fosters polarization and the impoverishment and exclusion of the already marginalized population.

Suburban contexts share a perceived high standard of living. They also have in common the proximity to main regional centres and available land for new business activities. In both cases, strategies for growth are settled by interest groups that use identity-building processes as a tool to mobilize capital. The effects are controversial: In the Italian case, the identity constructed and 
spread by interest groups is representative only of the wealthy part of the population. This discourse excludes a large part of the population. In the Austrian case, the internal tension between municipalities has led to a fragmented landscape, and the mobilization of cognitive capital remains low or limited to influential public and business actors.

The two rural cases are significantly different in terms of local-based development. The Austrian case has been engaged in fostering cohesion, local economy and demographic growth since 2001 and even before that as far as local development is concerned. The rural Italian case has been neglected over the last few years, and inhabitants are accustomed to a mentality of out-ward immigration, accepting the demographic decline and marginalization of the territory. In the Austrian case, the identity draws on the self-made rhetoric that is perceived as the territorial capital, more like the Italian suburban case, than the rural one. In the Italian rural case, there is no tradition of entrepreneurial spirit, and this is also one reason for the apparent lack of interest in local growth. Here, attempts to exploit the local assets are made by external actors in the name of regional interests, but they are not meet with enthusiasm or the engagement of local stakeholders. This last point is due to high and historical fragmentation between municipalities and a lack of collaboration, typical of several rural areas in Europe (Copus \& de Lima, 2015; Kristensen, Dubois, \& Teräs, 2019). Key agents and stakeholders of the Austrian case, instead, have intersecting and quite permanent roles within the communities, which benefits collaborations (similar to the Viennese city administration).

\section{Conclusion: Fragmentation, Civic Involvement and Identity in Mobilization}

While comparisons between material capital cannot translate into improving cohesion policies, given the diversity in size, natural assets, demographic trends and history, comparing mobilization strategies sheds light on pushing or hindering factors to beneficial uses of endogenous territorial capital. Therefore, identifying these factors in mechanisms of mobilization contributes to developing place-sensitive development strategies.

Narratives contained in public documents considerably stress the idea of a shared identity, regardless of the scale of the localities. If this narrative is shared by all local stakeholders, the mobilization of capital is more likely to be successful. Nevertheless, being an identity discourse conveyed only by specific stakeholders (e.g. business groups) or external actors that push for economic growth, the outcomes hardly foster social and territorial cohesion. This is evident in our urban and suburban cases. There, the dynamic does not include all local cognitive assets. Some of them, alongside with their territories, remain excluded from the overall mobilization efforts. This exclusion might be mitigated by the leading role of the authorities in places that suffer from frag- mentation (Milan and Vienna) and high turn-over (Milan). Fragmentation plays a pivotal role in hindering the efforts for mobilizing the capital. The Austrian suburban case and the Italian rural case are clear examples of that.

The lack of a shared identity weakens the efforts made by a single municipality (Ebreichsdorf) and external stakeholders (Oltrepo' Pavese). As highlighted by the interviews, the rhetoric spread by these actors is not shared by most residents, mayors or council representatives. Often, this results in the implementation of strategies and projects that clash with cohesion policy goals. Participation seems a key issue then. While civil society seems much livelier in cities, still it suffers from exclusion dynamics with some actors holding considerably more power and access to key networks, usually linked to economic resources. In smaller areas (suburban and rural), we find very different trends that relate again to fragmentation dynamics. Therefore, it is vital to identify inequality dynamics early on, in order to develop more successful locally-sensitive strategies for regional development. Not only in terms of fruitful mobilization of territorial capital but also in promoting cohesive and sustainable development.

Studies on mobilization strategies should consider the cognitive aspects of territorial capital and its contribution to local development. How policies enhance growth and cohesion, how they are built and conveyed (by which actors) is a relevant piece of the puzzle in understanding why territorial capital is mobilized successfully or not. What and who is excluded by the narratives is an important indicator as well as what is stressed and who the main conveyors of the discourse are. If growth policies are actually exclusive, they leave behind the weakest parts of the community, resulting in hindering cohesion. This exclusion is already built into some narratives that promote local growth policies.

\section{Acknowledgments}

We kindly thank Mathias Lipp and Michael Friesenecker for their contributions to data collection. This project has received funding from the European Union's Horizon 2020 research and innovation programme, under grant agreement No. 727058.

\section{Conflict of Interests}

The authors declare no conflict of interests.

\section{Supplementary Material}

Supplementary material for this article is available online in the format provided by the authors (unedited).

\section{References}

Affuso, A., Camagni, R., \& Capello, R. (2011). Quantitative foresights at sub-regional level: The model and 
estimation results. In R. Camagni \& R. Capello (Eds.), Spatial scenarios in a global perspective (pp. 91-110). Cheltenham: Edward Elgar.

AMS Austria (2018). Arbeitslosenquoten nach Arbeitsmarktbezirken und Geschlecht, Jahresdurchschnitt 2017 im Vergleich zu 2016 [Unemployment rates by districts and gender, annual average 2017 compared to 2016; Data set]. Retrieved from https://www.dnet. at/bali

Atkinson, R., Held, G., \& Jeffares, S. (2011). Theories of discourse and narrative: What do they mean for governance and policy? In R. Atkinson, G. Terizakis, \& K. Zimmermann (Eds.), Sustainability in European environmental policy: Challenges of governance and knowledge (pp. 115-130). London: Routledge.

Bonoli, G. (1997). Classifying welfare states: A twodimension approach. Journal of Social Policy, 26(3), 351-372.

Camagni, R. (2009). Territorial capital and regional competitiveness: Theory and evidence. In R. Capello \& P. Nijkamp (Eds.), Handbook of regional dynamics and growth: Advances in regional economics (pp. 118-132). Northampton, MA: Edward Elgar.

Camagni, R., \& Capello, R. (2013). Regional competitiveness and territorial capital: A conceptual approach and empirical evidence from the European Union. Regional Studies, 47(9), 1383-1402.

Capello, R., Caragliu, A., \& Nijkamp, P. (2009). Territorial capital and regional growth: Increasing returns in knowledge use. Journal of Economic and Social Geography, 102(4), 385-405.

Confindustria. (2015). Strategic plan of Confindustria Lombardia. Milan: Confindustria Lombardia.

Copus, A. K., \& de Lima, P. (2015). Territorial cohesion in rural Europe. The relational turn in rural development. Abingdon: Routledge.

Cucca, R. (2010). Crescita diseguale: Gli impatti sociali della transizione al post-Fordismo nelle città Europee [Unequal growth: Social impacts of the transition to post-Fordism in European cities]. Milan: Mondadori.

Esping-Andersen, G. (1990). The three worlds of welfare capitalism. Cambridge: Polity Press.

European Commission. (2005). Territorial state and perspectives of the European Union: Scoping document and summary of political messages. Brussels: European Commission.

Eurostat. (n.d.). Unemployment by sex, age and NUTS 2 regions (\%)-Annual data (Ifst_r_lfu3rt) [Data set]. Retrieved from https://appsso.eurostat.ec.europa. eu/nui/show.do?dataset=Ifst_r_Ifu3rt\&lang=en

Fratesi, U., \& Perucca, G. (2014). Territorial capital and the effectiveness of cohesion policies: An assessment for CEE regions. Investigaciones Regionales, 29, 165-191.

Gerhardter, G., \& Gruber, M. (2000). Förderungsaktion eigenständige Regionalentwicklung: Außenseiter oder Mitspieler in Österreichs Regionalpolitik? Evaluation der FER-Projektförderung 1979 bis 1999 [Promotion of independent regional development:
Outsiders or players in Austria's regional policy? Evaluation of the ERDF project funding 1979 to 1999]. Graz: Joanneum Research.

Gervais, M.-C., Morant, N., \& Penn, G. (1999). Making sense of "absence": Towards a typology of absence in social representations theory and research. Journal for the Theory of Social Behaviour, 29(4), 419-444.

Glaser, B. G. (1992). Basics of grounded theory analysis: Emergence vs forcing. Mill Valley, CA: Sociology Press.

Glaser, B. G., \& Strauss, A. L. (2009). The discovery of grounded theory: Strategies for qualitative research. New Brunswick, NJ: Aldine. (Original work published 1967)

Grozea-Helmenstein, D., Helmenstein, C., \& Neumüller, G. (2016). Die Entwicklung in den Regionen Niederösterreichs: Jahresbericht 2015 [The development in the regions of Lower Austria: Annual report 2015]. Vienna: Institute for Advanced Studies.

Italian National Institute of Statistics. (n.d.). ISTAT statistiche [ISTAT statistics]. Istituto Nazionale di Statistica. Retrieved from http://dati.istat.it

Kleinregion Ebreichsdorf Management, \& Emrich Consulting. (2011). Kleinregionales Rahmenkonzept Ebreichsdorf [Kleinregion framework concept Ebreichsdorf]. Vienna: Regionalmanagement Niederösterreich.

Kleinregion Ebreichsdorf Management, \& NÖ.regional. (2016). Kleinregionaler Strategieplan 2016-2020 Kleinregion Ebreichsdorf [Kleinregion strategic plan 2016-2020]. St.Pölten: NÖ.Regional GmbH.

Kleinregion Waldviertler Kernland Management. (2012). Kleinregionaler Strategieplan Waldviertler Kernland [Kleinregion strategy plan Waldviertler Kernland]. Ottenschlag: Kleinregion Waldviertler Kernland Management.

Kleinregion Waldviertler Kernland Management. (2016). Strategie Waldviertler Kernland 16-20 [Strategy Waldviertler Kernland 16-20]. Ottenschlag: Kleinregion Waldviertler Kernland Management.

Kornberger, M., \& Clegg, S. (2011). Strategy as performative practice. Strategic Organization, 9(2), 136-162.

Kristensen, I., Dubois, A., \& Teräs, J. (2019). Strategic approaches to regional development: Smart experimentation in less-favoured regions. Abingdon: Routledge.

Maillat, D. (1995). Territorial dynamic, innovative milieus and regional policy. Entrepreneurship and Regional Development, 7(2), 157-165.

Mayring, P. (2007). Qualitative Inhaltsanalyse [Qualitative content analysis]. In U. Flick, E. Kardoff, \& I. Steinke (Eds.), Qualitative Forschung: Ein Handbuch [Qualitative research: A handbook] (pp. 468-475). Hamburg: Rowohlt-Taschenbuch-Verlag.

Milan Municipal Council. (2014). Smart city document. Milan: Municipality of Milan.

Ministry of Territorial Cohesion. (2012). The inner area strategy. Rome: Ministry of Territorial Cohesion. 
Municipality of Milan. (2016). Manifattura Milano [Milan Manufacturing]. Milan: Urban Economy and Work Direction of the Municipality of Milan.

NÖ.regional. (2015). Hauptregionsstrategie Waldviertel 2024 [Main regional strategy Waldviertel 2024]. St. Pölten: NÖ.Regional GmbH.

OECD. (2001). OECD territorial outlook. Paris: OECD Publishing.

Perucca, G. (2014). The role of territorial capital in local economic growth: Evidence from Italy. European Planning Studies, 22(3), 537-562.

Ragin, C. C. (2014). The comparative method: Moving beyond qualitative and quantitative strategies. Berkeley, CA: University of California Press.

Ragin, C. C., \& Becker, H. S. (1992). Introduction: Cases of "what is a case?" In C. C. Ragin \& H. S. Becker (Eds.), What is a case? Exploring the foundations of social inquiry. Cambridge and New York, NY: Cambridge University Press.

Rihoux, B., \& Grimm, H. (2006). Innovative comparative methods for policy analysis: Beyond the quantitativequalitative divide. Boston, MA: Springer.

Schmidt, C. (2007). Analyse von Leitfadeninterviews [Analysis of guided interviews]. In U. Flick, E. Kardoff, \& I. Steinke (Eds.), Qualitative Forschung: Ein Handbuch [Qualitative research: A handbook] (pp.
447-456). Hamburg: Rowohlt-Taschenbuch-Verlag.

Servillo, S., Atkinson, R., \& Russo, A. P. (2011). Territorial attractiveness in EU urban and spatial policy: A critical review and future research agenda. European Urban and Regional Studies, 19(4), 349-365.

Statistics Austria. (n.d.). Registerzählung 2011 [Register census 2011]. Statistics Austria. Retrieved from https://www.statistik.at/web_de/statistiken/ menschen_und_gesellschaft/bevoelkerung/ volkszaehlungen_registerzaehlungen_ abgestimmte_erwerbsstatistik/index.html

Tosi, S., \& Vitale, T. (2011). Piccolo Nord: Scelte pubbliche $e$ interesssi privati nell' Alto Milanese [Little North: Public choices and private interests in Alto Milanese]. Milan: Mondadori.

Vienna Municipal Department 18. (2005). Urban development plan Vienna 2005. Vienna: Vienna Municipal Department 18-Urban Development and Planning.

Vienna Municipal Department 18. (2014a). Urban development plan Vienna 2025. Vienna: Vienna Municipal Department 18-Urban Development and Planning.

Vienna Municipal Department 18. (2014b). Smart city Wien: Framework strategy. Vienna: Vienna Municipal Department 18-Urban Development and Planning.

\section{About the Authors}

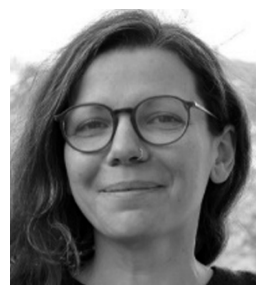

Tatjana Boczy is a Research Assistant at the Department of Sociology of the University of Vienna since 2018. Previously (2013-2014) she was an Undergraduate Research Assistant the Department of Sociology of the University of Innsbruck. She completed a master's degree in Sociology at the University of Innsbruck in 2017. Her research interests include urban and regional research, social change and transformations, political sociology, sociological theory and mixed-methods research.

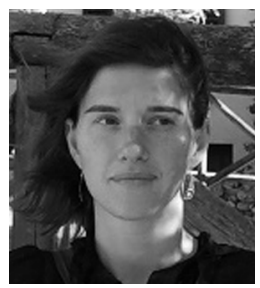

Marta Margherita Cordini is a Junior Researcher at the Department of Architecture and Urban Studies, Polytechnic of Milan. Her main interests include territorial inequalities, housing and school segregation. She teaches Urban Sociology at the Polytechnic of Milan. She is currently involved in the European project COHSMO and in several projects on educational inequalities. 